\title{
HOMOGENEITY ASSESSMENT OF MULTI-ELEMENT HETEROGENEOUS GRANULAR MIXTURES BY USING MULTIVARIATE ANALYSIS OF VARIANCE
}

\author{
Jolanta B. Krolczyk
}

Original scientific paper

The article presents a homogeneity analysis of multi-element heterogeneous granular mixtures. For this purpose, multivariate analysis of variance was used. The research study was conducted in an industrial feed production plant using a vertical mixer equipped with a worm agitator and with the mass of materials of $2,1 \div 2,2$ tones being put into it. Fodders comprising a dozen of whole seed components varying in grain diameter dimensions, densities and shapes were the subject of the research material. Homogeneity of fodder was determined based on samples taken during the bagging process. It was demonstrated - on the basis of statistical tests - that concentration of individual multi-elements, the heterogeneous granular mixtures is the same in the whole volume of the fodder. The mixtures are homogeneous (uniform), which is of vital significance, when considering the quality of mixtures being obtained. At this stage of production, there was no dissection of the mixture, and components were well-mixed. Furthermore, the hypothesis stating that shortening of the mixing time from standard mixing time of 30 to 20 minutes would not adversely affect the homogeneity of the mixture was verified.

Keywords: homogeneity assessment; mixing process; optimization; quality control; vertical mixer

Procjena homogenosti heterogene zrnate mješavine $s$ više sastojaka primjenom multivarijantne analize variance

Izvorni znanstveni članak Rad se bavi analizom homogenosti heterogenih zrnatih smjesa s više sastojaka. U tu se svrhu primijenila multivarijantna analiza variance. Istraživanje je provedeno u pogonu za proizvodnju krme koristeći vertikalni mikser s pužnom miješalicom u koji staje masa materijala od $2,1 \div 2,2$ tone. Analizirale su se krmne smjese sastavljene od desetak vrsta raznog sjemena s različitim dimenzijama zrna, različitih gustoća i oblika. Homogenost smjese određena je uzimanjem uzoraka tijekom punjenja vreća. Pokazalo se - na osnovu statističkih ispitivanja - da je koncentracija pojedinačnih multi-elemenata, heterogenih zrnatih mješavina ista u čitavoj količini krmne smjese. Smjese su homogene (jednolike), što je od bitne važnosti, kada se procjenjuje kvaliteta dobivenih smjesa. U tom stadiju proizvodnje nije bilo nikakvog razdvajanja smjese i sastojci su bili dobro izmiješani. Nadalje, verificirana je hipoteza da skraćivanje vremena miješanja od standardnih 30 na 20 minuta nema utjecaja na homogenost smjese.

Ključne riječi: kontrola kvalitete; optimizacija; postupak miješanja; procjena homogenosti; vertikalni mikser

\section{Introduction}

Mixing of granular materials is unquestionably important. The mixing process is a particular unit operation which occurs in a great number of practical applications and in every processing industry (mining, pharmaceuticals, energy, food and agriculture) $[1 \div 5]$. Mixing solids is common in industrial applications and frequently represents a critical stage of the processes [6]. The mixing process of granular materials is complex and comprehensive for theoretical recognition, because many factors affect its course [ $7 \div 9]$. The achieved effect of mixing and its speed are functions of multi parameters, including properties of components, the type of mixer, the mixing method, and conditions for conducting the process $[10,11]$. The process of secondary segregation is being observed frequently $[12 \div 14]$. The probable state of granular mixture, which will be obtained after a sufficiently long period of mixing components with similar properties, is the random state. The probability of finding the particle of specific component in the mixtures is the same at all points of the mixture. However, in the case of heterogeneous and multi-element granular systems, where significant differences in density, shape or average grain size are common, the description of the state of the mixture is one of fundamental problems in mixing $[13,15,16]$. A variety of devices and equipment are used for mixing granular materials $[10,17]$. This is a result of different needs from industry [18].

Mixing multi-element granular systems, such as fodders, as it comes out from industrial practices, is never perfectly homogenous, and status of such systems can be deduced explicitly on the basis of collected samples [13]. The homogeneity (uniformity) of compound feeds and fodders is crucial for food safety and for proper animal nutrition. The purpose of mixing is targeted to ensure proper proportions of individual components in each portion being dosed. Imprecise mixing of components, especially in the case of additives or active ingredients in feeds for health care purposes, being the result of both, an excess or either a deficiency of one of the components, for example of vitamins or medicament (antibiotic) - is undesirable and can cause negative effects. Inhomogeneous distribution of components in the mixture, the segregation process during mixing or in transport, and during filling the components into the mixer can cause negative side effects [19]. Manufacturer of animal feeds pays the attention to the quality of the mixture - on one hand, and to the costs of running the process, striving to optimise the process, on the other side $[20 \div 23]$. A satisfactory mixing process should produce a uniform mixture in minimum time and with minimum cost for overhead, power and labour. Nowadays companies are focusing on decreasing the production time while maintaining high quality manufacturing [24].

The objective of the article is to assess the homogeneity of several heterogeneous multi-element granular mixtures. Fodders for birds consisting of a dozen $(8,12$ and 14$)$ of whole grain components- grains varying according to their dimensions, densities or shapes - were subject of the research material. The research hypothesis is formulated as follows: the concentration of individual components in the mixture is uniform throughout the whole volume of the granular mixture. The homogeneity 
of the feed was determined on the basis of samples collected during the process of bagging. Furthermore the hypothesis stating that shortening the mixing time from 30 to 20 minutes would not adversely affect the homogeneity of the mixture was verified. The scope of research included conducting research experiments for the tested fodders consisting of 8,12 and 14 components.

\section{Material and methods}

Experimental studies were conducted at the mixing process line in an industrial feed mill. Diagram indicating the process of preparing the fodder starting from the stage of unloading of the raw material to the stage of final product is presented in Fig. 1. The mixing process was carried out in a vertical mixer equipped with a worm agitator (Fig. 2). Further information on dimensions of the mixer and on properties of the components (static bulk density and average dimension of grains) is indicated in the author's previous works $[25,26]$. The process was characterized by the recirculation of the components performed by the bucket elevator (Fig. 3). The poured granular material was emptied in the place of discharge, and then directed to the bucket elevator from which it went back to the mixer. Thus, the mixing took place owing to the movements of the mixing screw and the recirculation through the bucket elevator. The reason of recirculating the mixture was to clean seeds from small impurities (husks, shells, dust). Ingredients composition of the tested granular mixtures is shown in Table 1 and Fig. 4. The mixing time was 20 minutes. The mass of components entered into the mixer amounted to $2100 \mathrm{~kg}$ and $2200 \mathrm{~kg}$.

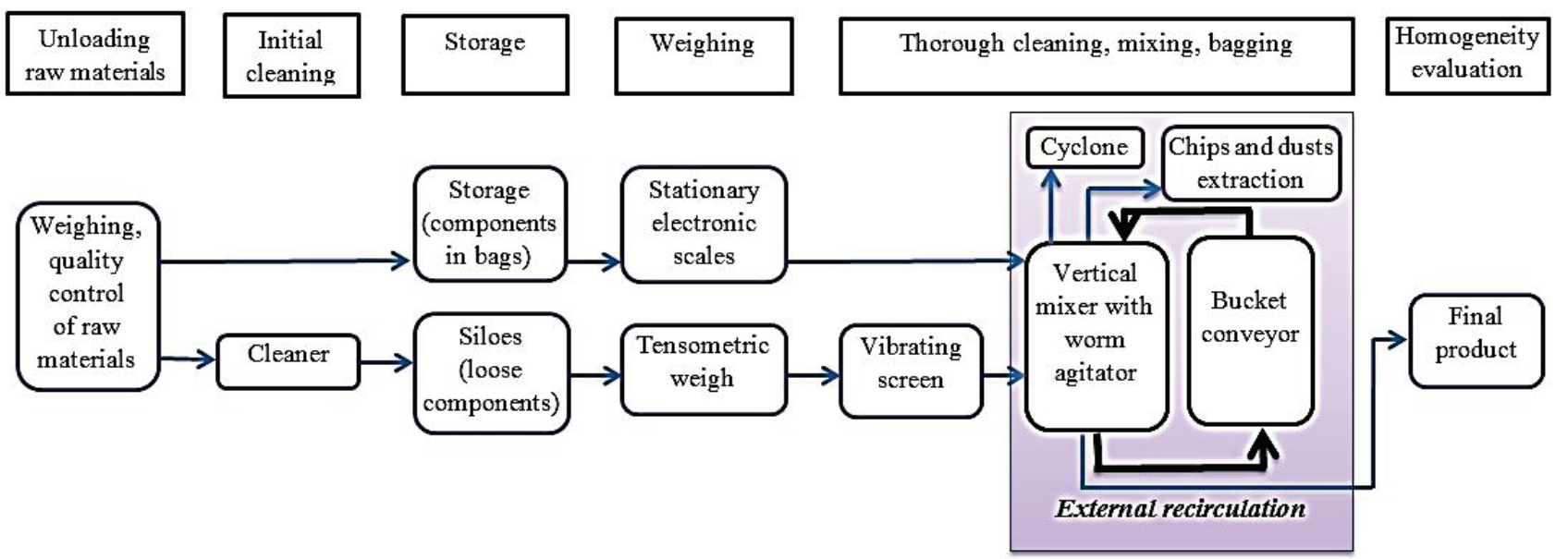

Figure 1 Schematic diagram of the industrial feed plant

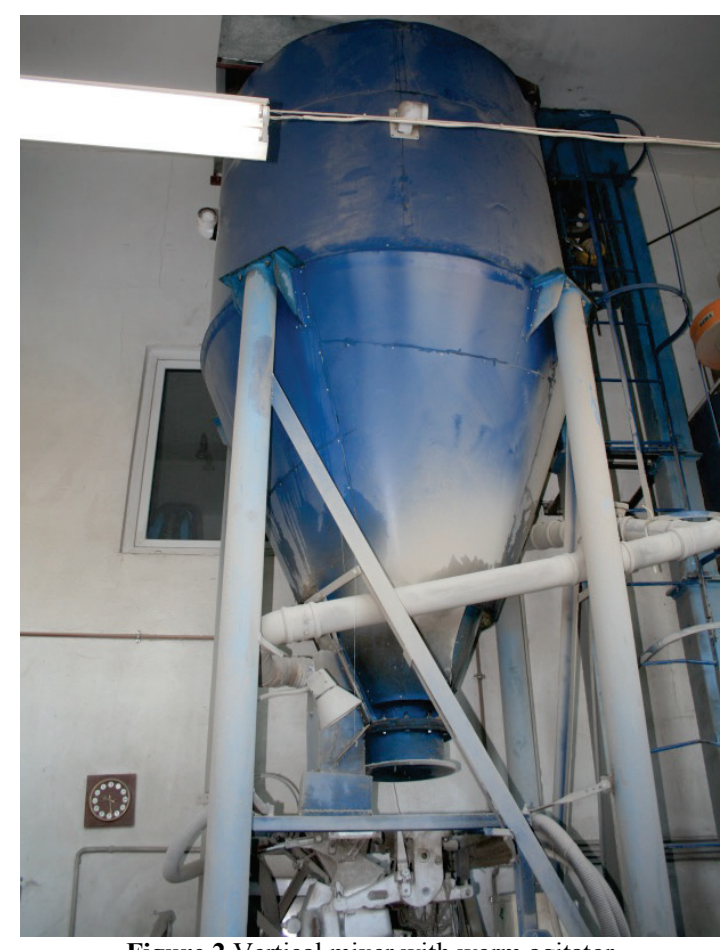

Figure 2 Vertical mixer with worm agitator

The experiment was to collect samples during bagging process in order to determine the homogeneity of mixtures from 10 selected bags (numbers of subsequent bags are given in Tab. 2). The mass of a single bag amounted to $25 \mathrm{~kg}$.

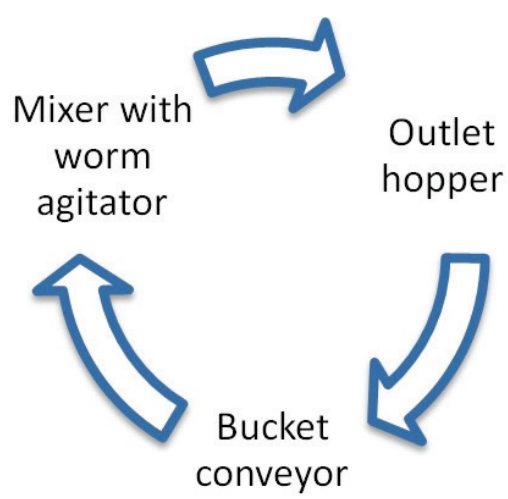

Figure 3 Schematic diagram of mixing

From each bag, three samples were collected- from three levels of the bag - further stated as bottom level (A), middle level (B) and upper level (C). During a single experiment, 30 specimens were collected. In total, 120 samples were taken for research study. Statistical analysis consisted of statistical tests with multivariate analysis of variance (MANOVA) to determine significant differences between the percentage share of individual components for three levels (A, B, C) for collecting specimens. On this basis, the homogeneity of the mixture was determined. 


\section{Results and discussion}

Statistical analysis was performed by using the SPSS Statistics software version 23. The average weight of samples taken during the experiment amounted to: for a mixture of 8 components: $244,54 \pm 45,18 \mathrm{~g}$, for a mixture of 12 components $(\mathrm{BF}): 250,76 \pm 57,05$, mixture of 14 components: $287,43 \pm 61,96(\mathrm{~N}=30)$, respectively. Below are presented selected results obtained for a single component in the 8-component mixture (Tab. 2). The table presents the results of the percentage share of maize obtained for three levels of collecting the samples (A, B, C).

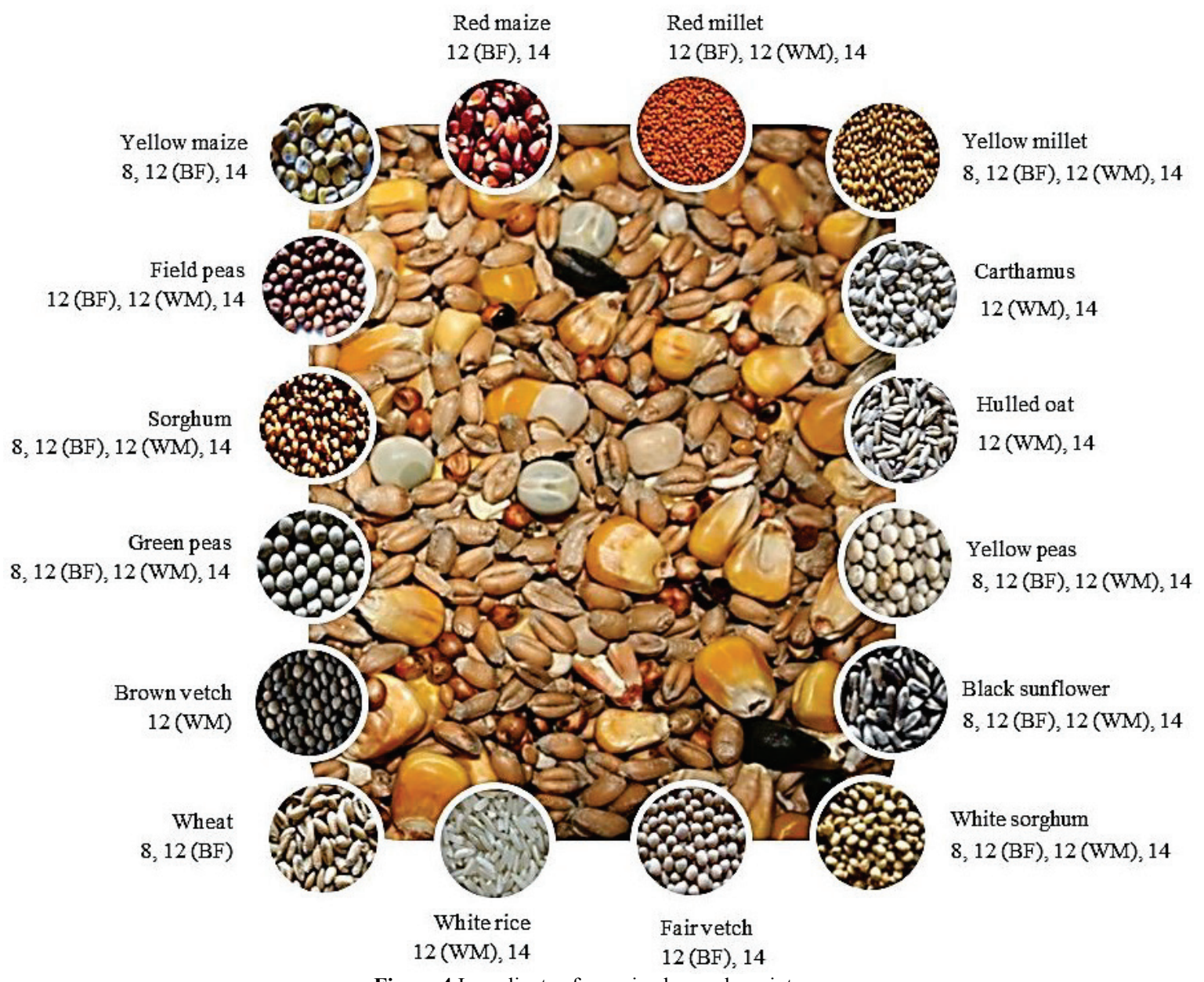

Figure 4 Ingredients of examined granular mixtures

Table 1 Composition of the examined granular mixtures

\begin{tabular}{|c|l|c|c|c|c|c|c|c|c|}
\hline \multirow{2}{*}{} & \multirow{2}{*}{ Components of the mixture } & \multicolumn{2}{|c|}{$\begin{array}{c}\text { 8-element granular } \\
\text { mixture (UN) }\end{array}$} & \multicolumn{2}{c|}{$\begin{array}{c}\text {-element granular } \\
\text { mixture (BF) }\end{array}$} & \multicolumn{2}{c|}{$\begin{array}{c}\text {-element granular } \\
\text { mixture (WM) }\end{array}$} & \multicolumn{2}{c|}{$\begin{array}{c}\text { 14-element granular } \\
\text { mixture (WW) }\end{array}$} \\
\cline { 3 - 10 } & & $\mathrm{kg}$ & $\%$ & $\mathrm{~kg}$ & $\%$ & $\mathrm{~kg}$ & $\%$ & $\mathrm{~kg}$ & $\%$ \\
\hline 1 & White sorghum & 20 & 0,95 & 50 & 2,27 & 250 & 11,90 & 150 & 7,14 \\
\hline 2 & Green peas & 80 & 3,81 & 80 & 3,64 & 300 & 14,29 & 120 & 5,71 \\
\hline 3 & Yellow peas & 190 & 9,05 & 140 & 6,36 & 510 & 24,28 & 200 & 9,52 \\
\hline 4 & Carthamus & - & - & - & - & 80 & 3,81 & 40 & 1,91 \\
\hline 5 & Red maize & - & - & 100 & 4,55 & - & - & 100 & 4,76 \\
\hline 6 & Yellow maize & 640 & 30,48 & 700 & 31,82 & - & - & 800 & 38,10 \\
\hline 7 & Hulled oat & - & - & - & - & 100 & 4,76 & 50 & 2,38 \\
\hline 8 & Field peas & - & - & 20 & 0,91 & 170 & 8,10 & 80 & 3,81 \\
\hline 9 & Red millet & - & - & 25 & 1,14 & 25 & 1,19 & 25 & 1,19 \\
\hline 10 & Yellow millet & 100 & 4,76 & 145 & 6,59 & 155 & 7,38 & 155 & 7,38 \\
\hline 11 & Wheat & 840 & 40,95 & 660 & 30,00 & - & - & - & - \\
\hline 12 & White rice & - & - & - & - & 50 & 2,38 & 25 & 1,19 \\
\hline 13 & Black sunflower & 30 & 1,43 & 30 & 1,36 & 90 & 4,29 & 60 & 2,86 \\
\hline 14 & Sorghum & 180 & 8,57 & 220 & 10,00 & 320 & 15,24 & 265 & 12,62 \\
\hline 15 & Brown vetch & - & - & - & - & 50 & 2,38 & - & - \\
\hline 16 & Fair vetch & - & - & 30 & 1,36 & - & - & 30 & 1,43 \\
\hline & & 2100 & 100 & 2200 & 100 & 2100 & 100 & 2100 & 100 \\
\hline
\end{tabular}


Table 2 Percentage share of yellow maize for three levels of sampling for 8-element granular mixture

\begin{tabular}{|c|c|c|c|c|}
\hline \multirow{2}{*}{ Lp. } & \multirow{2}{*}{$\begin{array}{c}\text { Sample } \\
\text { number }\end{array}$} & \multicolumn{3}{|c|}{ Percentage share / \% } \\
\cline { 3 - 5 } & Level 'A' & Level 'B' & Level 'C' \\
\hline 1 & 4 & 41,09 & 43,46 & 42,17 \\
\hline 2 & 12 & 46,33 & 48,92 & 49,06 \\
\hline 3 & 20 & 41,85 & 44,40 & 43,43 \\
\hline 4 & 28 & 33,19 & 33,97 & 37,02 \\
\hline 5 & 36 & 37,88 & 35,87 & 37,74 \\
\hline 6 & 44 & 33,34 & 36,51 & 35,81 \\
\hline 7 & 52 & 36,29 & 36,99 & 35,41 \\
\hline 8 & 60 & 40,41 & 40,11 & 38,84 \\
\hline 9 & 68 & 41,21 & 39,42 & 39,02 \\
\hline 10 & 76 & 49,30 & 50,44 & 50,11 \\
\hline
\end{tabular}

To assess the uniformity of granular mixture, the MANOVA was used. Multidimensional statistical methods are statistical techniques of simultaneous data analysis on a number of variables; therefore, this method was used to evaluate the homogeneity of the feed mixture. The MANOVA procedure is used to carry out the test for distinguishing differences between centroids in several populations [27].

In calculations the following was assumed:

1. Each of the $r$ of test populations is characterised by multivariate normal distribution.

2. All of $r$ populations have the same variance / covariance matrix $\Sigma$.

The null hypothesis is:

$\mathrm{H}_{0}: \mu_{1}=\mu_{2}=\mu_{3}=\ldots=\mu_{r}$

$\mathrm{H}_{1}$ : not all of $\mu_{i}(i=1,2, \ldots, r)$ are equal, wherein:

$\mu_{i}=\left[\begin{array}{c}\mu_{i 1} \\ \mu_{i 2} \\ \mu_{i 3} \\ \vdots \\ \mu_{i k}\end{array}\right]$

$\mu_{i}$ - average value of a vector in the $i^{\text {th }}$ population for the $k$ variable being tested that is the centroid of the $i^{\text {th }}$ population.

Thus, regarding the obtained results, $r=3(\mathrm{~A}, \mathrm{~B}, \mathrm{C}$ levels) and $k=8, k=11$ and $k=13$ (white sorghum, green pea, yellow pea, carthamus, red maize, yellow maize, hulled oat, field pea, red and yellow millet, wheat, white rice, black sunflower, sorghum, brown vetch, fair vetch). The components of red and yellow millet were analysed as a single component, while the explicit feature, which distinguished these components was the colour. However, due to obscurities in classifying some of the grains to a selected component, it was decided to combine these seeds as a single variable, which would prevent misstatement of the results of the analysis, during test specimen distribution into individual components.

The null hypothesis is:

$\mathrm{H}_{0}: \mu_{1}=\mu_{2}=\mu_{3}$ Centroids equal in $r$ of test populations.

Vectors of means at individual levels A, B, C (the level of collecting the sample in the bag) are homogeneous, which means that for mixes with 8, 11 and 13 components, respectively, the following is obtained:

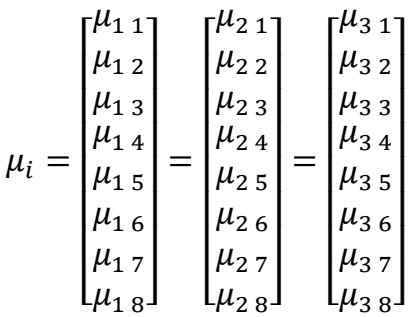

$\mu_{i}=\left[\begin{array}{l}\mu_{11} \\ \mu_{12} \\ \mu_{13} \\ \mu_{14} \\ \mu_{15} \\ \mu_{16} \\ \mu_{17} \\ \mu_{18} \\ \mu_{19} \\ \mu_{110} \\ \mu_{111}\end{array}\right]=\left[\begin{array}{l}\mu_{21} \\ \mu_{22} \\ \mu_{23} \\ \mu_{24} \\ \mu_{25} \\ \mu_{26} \\ \mu_{27} \\ \mu_{28} \\ \mu_{29} \\ \mu_{210} \\ \mu_{211}\end{array}\right]=\left[\begin{array}{l}\mu_{31} \\ \mu_{32} \\ \mu_{33} \\ \mu_{34} \\ \mu_{35} \\ \mu_{36} \\ \mu_{37} \\ \mu_{38} \\ \mu_{39} \\ \mu_{310} \\ \mu_{311}\end{array}\right]$

$\mu_{i}=\left[\begin{array}{l}\mu_{11} \\ \mu_{12} \\ \mu_{13} \\ \mu_{14} \\ \mu_{15} \\ \mu_{16} \\ \mu_{17} \\ \mu_{18} \\ \mu_{19} \\ \mu_{110} \\ \mu_{111} \\ \mu_{112} \\ \mu_{113}\end{array}\right]=\left[\begin{array}{l}\mu_{21} \\ \mu_{22} \\ \mu_{23} \\ \mu_{24} \\ \mu_{25} \\ \mu_{26} \\ \mu_{27} \\ \mu_{28} \\ \mu_{29} \\ \mu_{210} \\ \mu_{211} \\ \mu_{212} \\ \mu_{213}\end{array}\right]=\left[\begin{array}{l}\mu_{31} \\ \mu_{32} \\ \mu_{33} \\ \mu_{34} \\ \mu_{35} \\ \mu_{36} \\ \mu_{37} \\ \mu_{38} \\ \mu_{39} \\ \mu_{310} \\ \mu_{311} \\ \mu_{312} \\ \mu_{313}\end{array}\right]$

The alternative hypothesis is therefore:

$\mathrm{H}_{1}$ : not all of $\mu_{i}(i=1,2,3)$ vectors are equal, and $k=8, k$ $=11$ or $k=13$, where:

$\mu_{i}=\left[\begin{array}{c}\mu_{i 1} \\ \mu_{i 2} \\ \mu_{i 3} \\ \vdots \\ \mu_{i k}\end{array}\right]$

Four statistical tests were performed: the Pillai's trace, the Wilks' lambda, the Hotelling's trace, and the Roy's largest root to estimate the probability value of $p$ (Tab. 3).

The probability analysis $p$ (of $\alpha=0,05$ ) presented in Tab. 3, indicates that there is no reason to reject the null hypothesis on the equality of vectors of the expected values. It is assumed that centroids are equal in the examined populations, and thus, the average vectors at different levels A, B, C (the level of collecting the samples from the bag) can be considered as uniform. It can be concluded that mixtures with 8,12 and 14 components are uniform (homogeneous) in its composition, and each portion has a similar composition of the mixed components. The author's previous research 
studies assessed the homogeneity by using the MANOVA and the mixing process lasting 30 minutes [28, 29]. Three - based on different formulas - multi-element heterogeneous granular mixtures were analysed. The time has been set based on experiences of practitioners and in accordance with the mixer manufacturer's recommendations. In tests [28, 29] performed for 30 minutes of mixing, it was determined that these mixtures are homogeneous. The author's other research [18, 30] carried out for 30 minutes of mixing has previously indicated that the mixing time can be shortened by half, depends on the mixture's formula.

Table 3 The obtained values of significance $\mathrm{p}$ for statistical tests

\begin{tabular}{|c|c|c|c|c|c|}
\hline \multirow{2}{*}{ Lp. } & \multirow{2}{*}{$\begin{array}{c}\text { Type of } \\
\text { method }\end{array}$} & $\begin{array}{c}\text { 8- } \\
\text { element } \\
\text { granular } \\
\text { mixture } \\
\text { (UN) }\end{array}$ & $\begin{array}{c}\text { 12- } \\
\text { element } \\
\text { granular } \\
\text { mixture } \\
(\mathrm{BF})\end{array}$ & $\begin{array}{c}\text { 12- } \\
\text { element } \\
\text { granular } \\
\text { mixture } \\
(\mathrm{WM})\end{array}$ & $\begin{array}{c}14- \\
\text { element } \\
\text { granular } \\
\text { mixture } \\
(\mathrm{WW})\end{array}$ \\
\hline 1 & $\begin{array}{c}\text { Pillai's } \\
\text { trace }\end{array}$ & 0,850 & 0,590 & 0,211 & 0,313 \\
\hline 2 & $\begin{array}{c}\text { Wilks' } \\
\text { lambda }\end{array}$ & 0,872 & 0,532 & 0,235 & 0,328 \\
\hline 3 & $\begin{array}{c}\text { Hotelling's } \\
\text { trace }\end{array}$ & 0,892 & 0,487 & 0,262 & 0,349 \\
\hline 4 & $\begin{array}{c}\text { Roy's } \\
\text { largest root }\end{array}$ & 0,675 & 0,106 & 0,101 & 0,111 \\
\hline
\end{tabular}

The hypothesis of the research study was:

$\mathrm{H}$ : Mixing time may be shorter than the time (30 minutes) recommended by the manufacturer of the mixer, while preserving the frequency distribution of the tested grains, conforming to the model - the required composition of the feed mixture [30].

However, these considerations were performed based on analysis of samples collected at the time of mixing process during the above-mentioned recirculation of the components (compare Figs. 2 and 3). Then, samples were collected at the place of pouring out from the mixer. On the basis of the analysis on changes in statistical parameter using RSS (residual sum of squares) measurements, described in the author's publications [25, $30,32]$, it was determined that the time can be shorter than the time assumed by the manufacture of the fodder. But so far, this hypothesis was not verified by conducting experiment for shorter time, e.g. 20 minutes, as specified in this article. It was decided to verify this hypothesis in this publication. It was determined that the homogenous mixture was obtained, despite the fact that the time was decreased from 30 to 20 minutes - this is by $33 \%$. Therefore, the hypothesis was verified for four multielement granular mixtures with various recipes.

\section{Conclusions}

The results obtained show that the method used for assessment of mixture homogeneity has allowed the determination of product quality. This has been possible largely thanks to the proper design of the experiment and experimental methods. Based on the experimental observations, the author formulated the following conclusions:
1) On the basis of statistical tests it has been shown that there are no statistically significant differences between the percentage shares of individual components of the three levels of collecting the samples from bags. Therefore, the concentration of individual components in multi-element heterogeneous granular mixtures is uniform throughout the whole volume of the feed mixture.

2) Mixtures are homogeneous (uniform), which is of vital significance from the point of the quality of the mixtures. At this stage of production, there was no mixture stratification, and the components are well mixed. Quality of the obtained granular mixtures is good, considering as one of the aspects -its homogeneity.

3) The hypothesis on the feasibility of shortening the mixing time from 30 to 20 minutes while maintaining the homogeneity of obtained granular mixtures was confirmed by conducting four experiment tests. Each portion of the mixture contains homogeneous composition of components.

\section{References}

[1] Harnby, N. An engineering view of pharmaceutical powder mixing. // Pharmaceutical science \& technology today. 3, 9(2000), pp. 303-309. DOI: 10.1016/S1461-5347(00)00283-2

[2] Radl, S.; Kalvoda, E.; Glasser, B. J.; Khinast, J. G. Mixing characteristics of wet granular matter in a bladed mixer. // Powder Technology. 200, 3(2010), pp. 171-189. DOI: 10.1016/j.powtec.2010.02.022

[3] Mendez, A. S.; de Carli, G.; Garcia, C. V. Evaluation of powder mixing operation during batch production: application to operational qualification procedure in the pharmaceutical industry. // Powder Technology. 198, 2(2010), pp. 310-313. DOI: 10.1016/j.powtec.2009.11.027

[4] Królczyk, J. B.; Rezwiakow, A.; Tukiendorf, M. Mixing of biomass and coal in a static mixer as an example of technological solutions involving implementation of renewable energy sources. // Ecological Chemistry and Engineering S. 21, 4(2014), pp. 685-696. DOI: 10.1515/eces2014-0050

[5] Nedderman, R. M. Statics and Kinematics of Granular Materials, Cambridge University Press, 2005.

[6] Santomaso, A.; Olivi, M.; Canu, P. Mechanisms of mixing of granular materials in drum mixers under rolling regime. // Chemical Engineering Science. 59, 16(2004), pp. 32693280. DOI: 10.1016/j.ces.2004.04.026

[7] Revuzhenko, A. F. Mechanics of granular media, Springer Science \& Business Media, 2006.

[8] Radl, S.; Kalvoda, E.; Glasser, B. J.; Khinast, J. G. Mixing characteristics of wet granular matter in a bladed mixer. // Powder Technology. 200, 3(2010), pp. 171-189. DOl: 10.1016/j.powtec.2010.02.022

[9] Bridgwater J. Mixing of particles and powders: Where next? // Particuology. 8, 6(2010) pp. 563-567. DOI: 10.1016/j.partic.2010.07.001

[10] Bridgwater, J. Mixing of powders and granular materials by mechanical means-a perspective. // Particuology. 10, 4 (2012) pp. 397-427. DOI: 10.1016/j.partic.2012.06.002

[11] Rosato, A.; Strandburg, K. J.; Prinz, F.; Swendsen, R. H. Why the Brazil nuts are on top: Size segregation of particulate matter by shaking. // Physics Review Letters. 58, (1987), pp. 1038-1040. DOI: 10.1103/PhysRevLett.58.1038

[12] Ottino, J. M.; Khakhar, D. V. Mixing and segregation of granular materials. // Annu. Rev. Fluid Mech. 32, (2000), pp. 55-91. DOI: 10.1146/annurev.fluid.32.1.55 
[13] Boss, J. Solid mixing process. PWN, Warszawa - Wrocław 1987. (in Polish)

[14] Hogg, R. Mixing and Segregation in Powders: Evaluation, Mechanisms and Processes. // KONA Powder and Particle Journal. 27, (2009), pp. 3-17. DOI: 10.14356/kona.2009005

[15] Cullen, P. J. Food Mixing: Principles and Applications. Hardcover, Wiley-Blackwell (2009). ISBN 978-1-40517754-2.

[16] Daumann, B. H.; Nirschl, H. Assessment of the mixing efficiency of solid mixtures by means of image analysis. // Powder Technology. 182, (2008), pp. 415-423. DOI: 10.1016/j.powtec.2007.07.006

[17] Harnby, N. An engineering view of pharmaceutical powder mixing. // Pharmaceutical science \& technology today. 3, 9 (2000), pp. 303-309. DOI: 10.1016/S1461-5347(00)00283-2

[18] J. Królczyk, S. Legutko, Devices and equipment for mixing granular materials in industry. // Applied Mechanics and Materials. 809-810, (2015), pp. 742-747. DOl: 10.4028/www.scientific.net/AMM.809-810.742

[19] Neumann, K. D. Work of the mixer is crucial for additives. Kraftfutter, 2000.

[20] Bauman, I.; Ćurić, D.; Boban, M. Mixing of solids in different mixing devices. // Sadhana. 33, 6(2008), pp. 721731. DOI: $10.1007 / \mathrm{s} 12046-008-0030-5$

[21] Djuragic, O.; Levic, J.; Sredanovic, S.; Lević, L. Evaluation of homogeneity in feed by method of microtracers ${ }^{\circledR}$. // Archiva Zootechnica. 12, 4(2009), pp. 85-91.

[22] Mann, H. Benefiting from quality management. Sampling procedures for feed ingredients. // Amino News. 5, 1(2004), pp. 19-26.

[23] Putier, F. Assessment of homogenity of compound feed. // Feed Magazine. 3(2001), pp. 98-108.

[24] Obregón, L.; Realpe, A.; Rinaldi, C.; Velázquez, C. Mixing of granular materials. Part I: Effect of periodic shear. // Powder Technology. 197, (2010), pp. 9-16. DOI: 10.1016/j.powtec.2009.08.014

[25] Krolczyk, J. B. An attempt to predict quality changes in a ten-component granular system. // Tehnicki VjesnikTechnical Gazette. 21, 2(2014), pp. 255-261.

[26] Krolczyk, J. B. The Use of the Cluster Analysis Method to Describe the Mixing Process of the Multi-Element Granular Mixture. // Transactions of FAMENA. 38, 4(2015), pp. 4354.

[27] Aczel, A. D. Statystyka w zarządzaniu. PWN, Warszawa, 2005.

[28] Królczyk J. Ocena jednorodności jedenastoskładnikowej mieszanki pasz. // Inżynieria Rolnicza. 2, 143(2013). pp. 175-181.

[29] Królczyk J. Zastosowanie wielowymiarowej analizy wariancji do oceny rozmiaru próby wieloskładnikowych pasz. // Inżynieria Rolnicza. 2, 143(2013), pp. 183-189.

[30] Królczyk J.Proces mieszania wieloskładnikowych materiałów ziarnistych $\mathrm{w}$ urządzeniu $\mathrm{z}$ mieszadłem ślimakowym. Opole 2007, Praca doktorska.

[31] Królczyk J. B. Industrial Conditions of the Granular Material Manufacturing Process. // Applied Mechanics and Materials. 693, (2014) pp. 267-272. DOl: 10.4028/www.scientific.net/AMM.693.267

\section{Author's address}

Jolanta B. Krolczyk, PhD Eng.

Opole University of Technology

76 Proszkowska Street, 45-758 Opole, Poland

E-mail: j.krolczyk@po.opole.pl 